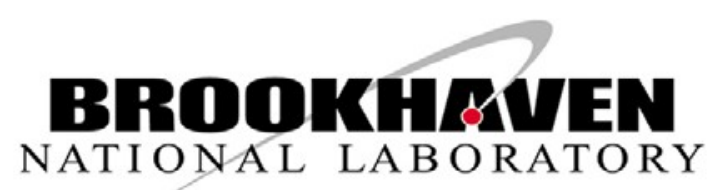

BNL-114132-2017-JA

\title{
Evaluation of Biomass-Derived Distillate Fuel as Renewable Heating Oil
}

\author{
O. D. Mante
}

Submitted to American Chemical Society

September 2015

\author{
Sustainable Energy Technologies Department \\ Brookhaven National Laboratory
}

\section{U.S. Department of Energy \\ USDOE Office of Energy Efficiency and Renewable Energy (EERE), Fuel Cell Technologies Program (EE-3F)}

Notice: This manuscript has been authored by employees of Brookhaven Science Associates, LLC under Contract No. DE- SC0012704 with the U.S. Department of Energy. The publisher by accepting the manuscript for publication acknowledges that the United States Government retains a non-exclusive, paid-up, irrevocable, world-wide license to publish or reproduce the published form of this manuscript, or allow others to do so, for United States Government purposes. 


\section{DISCLAIMER}

This report was prepared as an account of work sponsored by an agency of the United States Government. Neither the United States Government nor any agency thereof, nor any of their employees, nor any of their contractors, subcontractors, or their employees, makes any warranty, express or implied, or assumes any legal liability or responsibility for the accuracy, completeness, or any third party's use or the results of such use of any information, apparatus, product, or process disclosed, or represents that its use would not infringe privately owned rights. Reference herein to any specific commercial product, process, or service by trade name, trademark, manufacturer, or otherwise, does not necessarily constitute or imply its endorsement, recommendation, or favoring by the United States Government or any agency thereof or its contractors or subcontractors. The views and opinions of authors expressed herein do not necessarily state or reflect those of the United States Government or any agency thereof. 


\title{
Evaluation of Biomass-Derived Distillate Fuel as Renewable Heating Oil
}

\author{
Ofei D. Mante, ${ }^{\dagger, \dagger}$ Thomas A. Butcher, ${ }^{* \dagger}{ }^{\dagger}$ George Wei, ${ }^{\dagger}$ Rebecca Trojanowski, ${ }^{\dagger}$ and Vicente Sanchez ${ }^{\S}$ \\ ${ }^{\dagger}$ Sustainable Energy Technologies Department, Brookhaven National Laboratory (BNL), Upton, New York 11973, United States \\ ${ }^{\ddagger}$ RTI International, Research Triangle Park, North Carolina 27709, United States \\ ${ }^{\S}$ KiOR, Incorporated, Pasadena, Texas 77507, United States
}

\begin{abstract}
The utilization of advanced biofuels in stationary applications, such as home heating, is considered as an early entry point for biomass-derived fuels into the distillate fuel market sector. Two renewable fuels produced by a biomass fluidized catalytic cracking (BFCC) process, followed by hydroprocessing and fractionation, were tested. The evaluation was performed on a pure (100\%) distillate fraction, $50 \%$ blend of the distillate fraction with petroleum-based heating oil, and $20 \%$ blend of a heavier gas oil fraction. Combustion experiments were carried out in a transparent quartz chamber and a typical oil-fired residential boiler. The flame stability, size, and shape produced by the fuels were examined. The flue gas was analyzed for $\mathrm{O}_{2}, \mathrm{CO}, \mathrm{NO}_{x}$, and smoke. The elastomer compatibility test was performed with nitrile slabs at $43{ }^{\circ} \mathrm{C}$ for 1 month. Fuel stability was examined at 80 ${ }^{\circ} \mathrm{C}$ for 1 week. The results from the combustion studies suggest that the distillate fuel blends could be used as alternative fuels to No. 2 heating oil, even up to $100 \%$ without any operational issues. The distillate fuels were found to be stable. and the nitrile slab volume swell $(\sim 10 \%)$ suggests that the fuel could be compatible to legacy elastomers.
\end{abstract}

\section{INTRODUCTION}

Home-heating oil ( $\mathrm{HHO})$ is an important source of energy for space heating during winter seasons, especially in the northeastern region of the United States. According to the U.S. Energy Information Administration (EIA), about 7 million households used $\mathrm{HHO}$ in 2012 and the northeastern region represents $87 \%$ of the total U.S. residential fuel oil sales. ${ }^{1}$ These data are indicative of the strong reliance of the region on heating oil, and such a dependency makes the region vulnerable to heating oil supply and prices. Thus, any HHO shortage crisis could have an adverse economic effect on consumers.

It is therefore imperative to explore the use of renewable fuels as substitutes for petroleum-derived HHO. Such a strategy could potentially help reduce heating oil price volatility and ensure stable supply for homeowners that depend upon heating oil as their main space heating fuel. ${ }^{2}$ Besides, the use of renewable fuels will reduce greenhouse gas emissions, ${ }^{3,4}$ reduce petroleum imports, ${ }^{5}$ and create jobs in the U.S. Furthermore, utilization of biofuels in stationary applications, such as boilers and furnaces, may provide an early point of entry for renewables into the oil market sector. ${ }^{2}$

No. 2 distillate is the main fuel oil grade that is used in small residential- and commercial-sized fuel oil-burning equipment. The interest in using biofuels in recent years has spurred the use of distillate blends with biodiesel. ${ }^{6,7}$ According to ASTM D396, ${ }^{8}$ any fuel oil containing up to 5 vol \% biodiesel that meets the requirement of specification ASTM D6751 ${ }^{9}$ is considered as heating oil. Higher fuel blends of biodiesel that meet the ASTM D6751 ${ }^{9}$ quality standard are also used in the northeast. The progress made with the use of biodiesel may pave the way for the introduction of other renewable fuels, such as those derived from biomass pyrolysis.

As studies have shown, pyrolysis oils produced from biomass have the potential to be used as a heating oil substitute. ${ }^{10-14}$
However, raw pyrolysis oil, unlike biodiesel, does not have comparable physical properties and chemical composition as petroleum diesel, and this presents a great challenge for its broad use as a heating fuel. ${ }^{11,15}$ Therefore, successful utilization of pyrolysis oils in the heating market would require further catalytic upgrading $^{16-19}$ of the raw oil by either hydroprocessing, ${ }^{20-23}$ catalytic cracking, or a combination of both and final fractionation into a refined oil that meets the technical specification for acceptable use as $\mathrm{HHO}$ and can be blended with petroleum-based fuels. At the moment, a number of research institutions, universities, and organizations are developing and demonstrating technologies capable of producing such fungible fuels from the raw pyrolysis oils. These include KiOR (biomass fluid catalytic cracking and hydrotreating), ${ }^{24}$ Envergent (fast pyrolysis and hydroprocessing), ${ }^{25}$ Anellotech (catalytic pyrolysis), ${ }^{26}$ RTI International (biomass catalytic pyrolysis), ${ }^{27}$ and Gas Technology Institute (hydropyrolysis and $\mathrm{IH}^{2}$ process). ${ }^{28-30}$

In general, for any renewable fuel to be accepted by the heating oil market sector, performance must be demonstrated throughout the supply, distribution, and end use system. Thus, potential issues, such as miscibility, stability, legacy elastomer and metals compatibility, and combustion performance, including ignition, flame stability, control system response, and air pollutant emissions, need to be addressed for biomass pyrolysis-based fuels.

The Bioenergy Technologies Office (BETO) of the U.S. Department of Energy (DOE) held a technical information exchange workshop in May 2012 to explore opportunities for upgraded pyrolysis oil as a renewable heating oil substitution

Received: July 31, 2015

Revised: September 14, 2015 
fuel in New England. ${ }^{2}$ A number of barriers that need to be overcome to enable the use of upgraded pyrolysis oil for home heating were identified. The topical areas of discussion included the following: feedstocks and production, logistics and compatibility, operational issues, and market engagement and acceptance. On the basis of the inputs from the workshop, it was suggested that upgraded pyrolysis oil could potentially replace $20 \mathrm{wt} \%$ of No. 2 heating oil in the northeast. ${ }^{2}$ The target of $20 \%$ was selected only because there has been considerable successful evaluation of biodiesel blends at this level and it is seen as having significant impact potential. This blend level was considered to be only for initial testing. If successful, higher blend levels would certainly be targeted.

This work was subsequently pursued as part of a collaborative effort in testing, evaluating, and qualifying upgraded pyrolysis oils for home-heating applications. The investigation was pursued purposely to evaluate fully upgraded pyrolysis oils, which can be considered as a "drop-in" fuel, capable of displacing No. 2 fuel oil in home-heating systems. For this reason, renewable distillate and fuel oil samples produced from biomass by KiOR, Inc. (Pasadena, TX) were tested in an unmodified residential-size burner with simplex pressure-swirl nozzles. The tests were performed on $100 \%$ KiOR distillate, $50 \%$ blend of KiOR distillate, and $20 \%$ blend of KiOR fuel oil (gas oil). The No. 2 fuel oil used for blending was ultra-low sulfur $(<15 \mathrm{ppm})$ as currently required by New York State. Results from the evaluation of legacy elastomer compatibility, stability, combustion performance, and air pollutant emissions are reported.

\section{MATERIALS AND METHODS}

2.1. Test Fuels. In this work, biomass-derived fuels that could attain commercial status and may be a "drop-in" fuel, capable of displacing No. 2 fuel oil in home-heating systems, were of interest. Two fuel samples, "distillate" and "gas oil", were supplied by KiOR, Inc. (Pasadena, TX) for testing. The ultra-low-sulfur diesel (ULSD) heating oil used for blending was purchased from a local supplier.

The biomass-derived fuels were produced from solid biomass, specifically powdered-debarked Southern Yellow Pine, using a threestep process. The biomass fluidized catalytic cracking (BFCC) process is the first conversion step in the process platform of KiOR. In this step, KiOR uses a proprietary catalyst to react with the biomass within seconds to produce intermediate bio-oils containing a complex mixture of hydrocarbons and oxygen-containing organic compounds, with an elemental oxygen content of $<30 \%$ (by mass). Hydroprocessing is the next step to remove oxygen from the intermediate bio-oil. The bio-oil is processed through a hydrotreating unit in the presence of hydrogen at a high pressure, to remove the organic oxygen and transform the oxygenated compounds to hydrocarbons. Fractionation is the final process to produce the upgraded products. A distillation column is used to separate naphtha and distillate cuts overhead and fuel oil bottoms. The last fractionation processing step also insures that any heavy materials, impurities, or solids will be removed and will not contaminate the distillate product. Many technical aspects of the KiOR process have been covered in a suite of patents.

2.2. Combustion Studies. Two separate combustion experiments were conducted for each fuel blend. The first combustion test was performed using a transparent quartz combustion chamber equipped with a Carlin EZ-1HP oil burner (Carlin Combustion Technology, Inc., North Haven, CT). The installed burner is a conventional, pressure-atomized oil burner with a commonly used swirl nozzle, primary control, and solenoid oil shutoff valve.

The control system for this burner uses a cadmium sulfide photoresistor sensor ("cad cell") as part of the safety system. The function of this sensor and the associated control is to stop fuel flow in the event of a no-flame condition to prevent flooding of the chamber.
The flame is proven with a resistance of this sensor under $3500 \Omega$. One of the parameters monitored during the tests was the resistance of this sensor to evaluate the potential for control response concerns. Beyond the control operation, the resistance of this sensor provides some additional information on the flame. A flame with less emissivity would produce less light and a higher sensor resistance. Flames with poor stability lead to high and fluctuating resistance signals.

The quartz chamber combustion test was performed to provide a basic visual evaluation of flame stability, size, and shape relative to the $100 \%$ ULSD oil. The second test was carried out in a Dunkirk boiler, model 3EW1.00Z, with an input of $140 \mathrm{MBH}(140000 \mathrm{Btu} / \mathrm{h})$ and heating capacity of $119 \mathrm{MBH}$ (Dunkirk Boilers, Utica, NY). This residential boiler is very representative of northeast, oil-fired heating systems. It is a three-section, cast iron boiler with a tankless coil installed for domestic hot water. The same Carlin EZ-1HP oil burner used in the quartz chamber studies was used in the Dunkirk boiler. For this test, the burner was adjusted to an excess air level, which provides a "smoke number" of zero but is just above the excess air level at which air flow is too low and smoke number increases. Burners are typically adjusted in this way to provide the highest efficiency possible consistent with clean combustion. Following a careful tuning procedure to achieve this condition, the burner was operating at roughly $15 \%$ excess air, which is rather low for this type of equipment. This could be considered an "ideal" tune situation. A Testo 350-XL flue gas analyzer was used to monitor $\mathrm{O}_{2}, \mathrm{CO}$, and $\mathrm{NO}_{x}$. The analyzer was calibrated prior to its use. Other performance metrics, including smoke number and cad cell value, were also evaluated. Smoke number measurements were made following ASTM D2156. ${ }^{31}$ In each combustion experiment, a dual-fuel feeding train equipped with a standard $10 \mu \mathrm{m}$, felt fuel oil filter was employed to allow for seamless switching between the 100\% ULSD and the fuel being tested during boiler operation. Such a system permitted a direct comparison between the combustion performances of the fuels. For all of the tests, the combustion system was first started and warmed on 100\% ULSD and, after establishing baseline data, the fuel supply was switched to the test fuel. Thus, the testing proceeded as follows: ULSD-test fuelULSD. In addition to these tests, the $100 \% \mathrm{KiOR}$ distillate was subjected to cyclic condition combustion at a rate of $2 \mathrm{~h}$ per cycle over a period of 4 days to evaluate consistency of ignition and routine operation.

All combustion studies were conducted under carefully controlled conditions following a formal safety review by the Directorate Research Operations group at BNL.

2.3. Elastomer Swell Test. For each fuel blend, the volume swell of hard nitrile slabs used in the lip seal on the most common pump in the U.S. was evaluated. The test material was obtained from the pump manufacturer (Suntec Industries). In general, nitrile materials differ greatly depending upon composition and use of additives, and therefore, it is important to use the actual material for the swell tests. Specimen of approximate dimensions, $12.5 \times 25 \times 2.0 \mathrm{~mm}$, were made and used for the tests. The swell tests were conducted following similar protocols described in ASTM D471 $1^{32}$ and UL 157. ${ }^{33}$ Each specimen was immersed with the use of a thin Kanthal wire fitted to a stopper in a total volume of $25 \mathrm{~mL}$ of the test liquid. The swell was determined by measuring the length $(l)$, width $(w)$, and thickness $(t)$ of the specimen before and after the specified exposure period. The change in volume was then computed as follows:

$$
\Delta V(\%)=\frac{(L W T)-(l w t)}{l w t} \times 100
$$

where $l, w$, and $t$ are the length, width, and thickness of the specimen before the immersion and exposure, respectively, and $L, W$, and $T$ are the length, width, and thickness of the specimen after the immersion and exposure, respectively.

2.4. Storage Stability at $80{ }^{\circ} \mathrm{C}$. The storage stability of the fuel blends was performed at $80{ }^{\circ} \mathrm{C}$ for 1 week. This accelerated storage stability test has been shown to have good correlation with ASTM $\mathrm{D} 4625,{ }^{34}$ and the amount of total insolubles formed in each method is comparable. Three $50 \mathrm{~mL}$ samples of each fuel were filtered $(0.8 \mu \mathrm{m})$ and then stored at $80{ }^{\circ} \mathrm{C}$ for 1 week in uncapped $25 \times 200 \mathrm{~mm}$ heavy 
Table 1. Properties of Test Fuels

\begin{tabular}{|c|c|c|c|c|c|c|}
\hline \multirow[b]{2}{*}{ physical properties } & \multirow[b]{2}{*}{ ASTM test method } & \multirow[b]{2}{*}{$\begin{array}{l}\text { D396 } \\
\text { limits }\end{array}$} & \multicolumn{2}{|c|}{ standard No. 2 fuels $^{a}$} & \multicolumn{2}{|c|}{ test fuels } \\
\hline & & & No. 2 S500 & No. 2 S5000 & $\begin{array}{c}\mathrm{KiOR} \\
\text { distillate }\end{array}$ & KiOR gas oil \\
\hline flash point $\left({ }^{\circ} \mathrm{C}\right)$ & D39 & $\min$ & 38 & 38 & 60 & 129 \\
\hline water and sediment (vol \%) & D2709 & $\max$ & 0.05 & 0.05 & 0.0001 & 0.09 \\
\hline distillation $\left({ }^{\circ} \mathrm{C}\right)$ & D86 & & & & & \\
\hline IBP & & & & & 169 & \\
\hline $50 \%$ & & & & & 257 & \\
\hline $90 \%$ & & $\min$ & 282 & 282 & 326 & \\
\hline $90 \%$ & & $\max$ & 338 & 338 & & \\
\hline FBP & & & & & 347 & \\
\hline kinematic viscosity at $40{ }^{\circ} \mathrm{C}\left(\mathrm{mm}^{2} / \mathrm{s}\right)$ & D445 & $\min$ & 1.9 & 1.9 & 2.9 & 834 \\
\hline & & $\max$ & 4.1 & 4.1 & & \\
\hline Ramsbottom carbon residue on $10 \%$ distillation residue (mass \%) & D524 & $\max$ & 0.35 & 0.35 & 0.11 & \\
\hline sulfur $(\mathrm{ppm})$ & D7039 & $\max$ & 500 & 5000 & 7.3 & 5.6 \\
\hline copper strip at $50{ }^{\circ} \mathrm{C}$ & D 130 & $\max$ & No. 3 & No. 3 & No. 1a & \\
\hline density at $15^{\circ} \mathrm{C}\left(\mathrm{kg} / \mathrm{m}^{3}\right)$ & D1298 & $\max$ & 876 & 876 & 903 & 958 \\
\hline pour point $\left({ }^{\circ} \mathrm{C}\right)$ & D97 & $\max$ & -6 & -6 & $<-60$ & -6 \\
\hline cloud point $\left({ }^{\circ} \mathrm{C}\right)$ & D2500 & $\mathrm{ND}^{b}$ & ND & ND & $<-50$ & \\
\hline acid number $(\mathrm{mg}$ of $\mathrm{KOH} / \mathrm{g})$ & D664 & ND & ND & ND & $<0.02$ & \\
\hline carbon + hydrogen content (mass \%) & D5291 & ND & ND & ND & 99.9 & \\
\hline nitrogen content (ppm) & D4629 & ND & ND & ND & $<20$ & \\
\hline
\end{tabular}
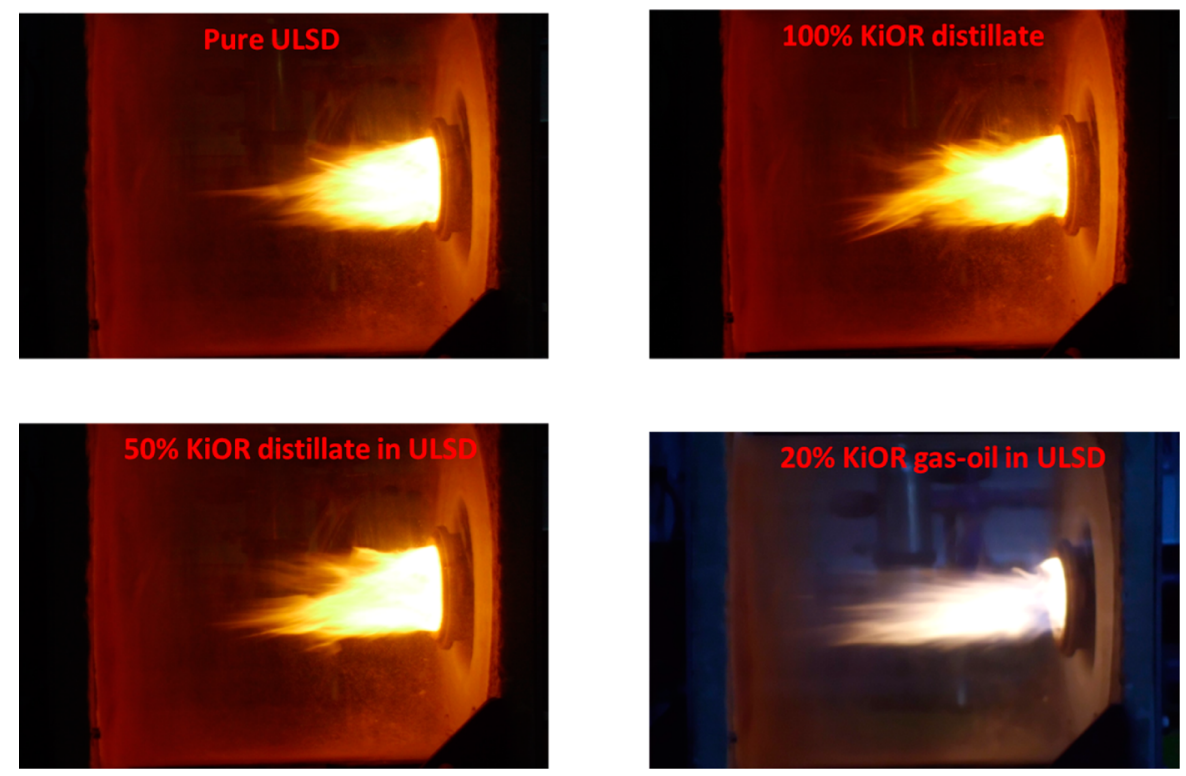

Figure 1. Appearance of flames of ULSD, $100 \%$ KiOR distillate, $50 \%$ KiOR distillate blend, and $20 \%$ KGO blend in the quartz transparent combustion chamber.

wall glass test tubes. After aging, the samples were cooled and filtered through a preweighed, oven-dried $47 \mathrm{~mm}$ nylon filter (nominal pore size of $0.8 \mu \mathrm{m}$ ) under vacuum. Isooctane was used to rinse the filter, funnel, and test tubes to remove trace fuel. The test tubes were ovendried afterward and weighed prior to washing out the adherent insolubles with trisolvent (equal volume mixture of methanol, acetone, and toluene). After washing, the test tubes were oven-dried and weighed again. Oven drying of filter papers and test tubes were performed at $90{ }^{\circ} \mathrm{C}$ for $30 \mathrm{~min}$. The total yield of insolubles in milligrams per $100 \mathrm{~mL}$ was determined gravimetrically.

\section{RESULTS AND DISCUSSION}

3.1. Properties of Test Fuels. Table 1 shows the properties of the pure KiOR distillate and gas oil (KGO) fuels in comparison to the specification of No. 2 heating oil as defined in ASTM D396. ${ }^{8}$ From the viewpoint of the measured properties, it can be seen that the KiOR distillate fuel, in particular, is extremely suitable for home heating because it meets most of the ASTM D396 ${ }^{8}$ requirements for No. 2 fuel. The main limitation of the KiOR distillate fuel is its density. The maximum density specified for No. 2 is $876 \mathrm{~kg} / \mathrm{m}^{3}$. On the basis of that, the KiOR distillate fuel can be blended up to $50 \%$ and still meet ASTM D396 ${ }^{8}$ specification for heating oil. Additionally, the lower sulfur content and superior cold flow property (cloud point lower than $-50{ }^{\circ} \mathrm{C}$ ) of the $\mathrm{KiOR}$ distillate fuel make it very attractive. For instance, in New York State, No. 2 heating oil is mandated to have a sulfur content of 


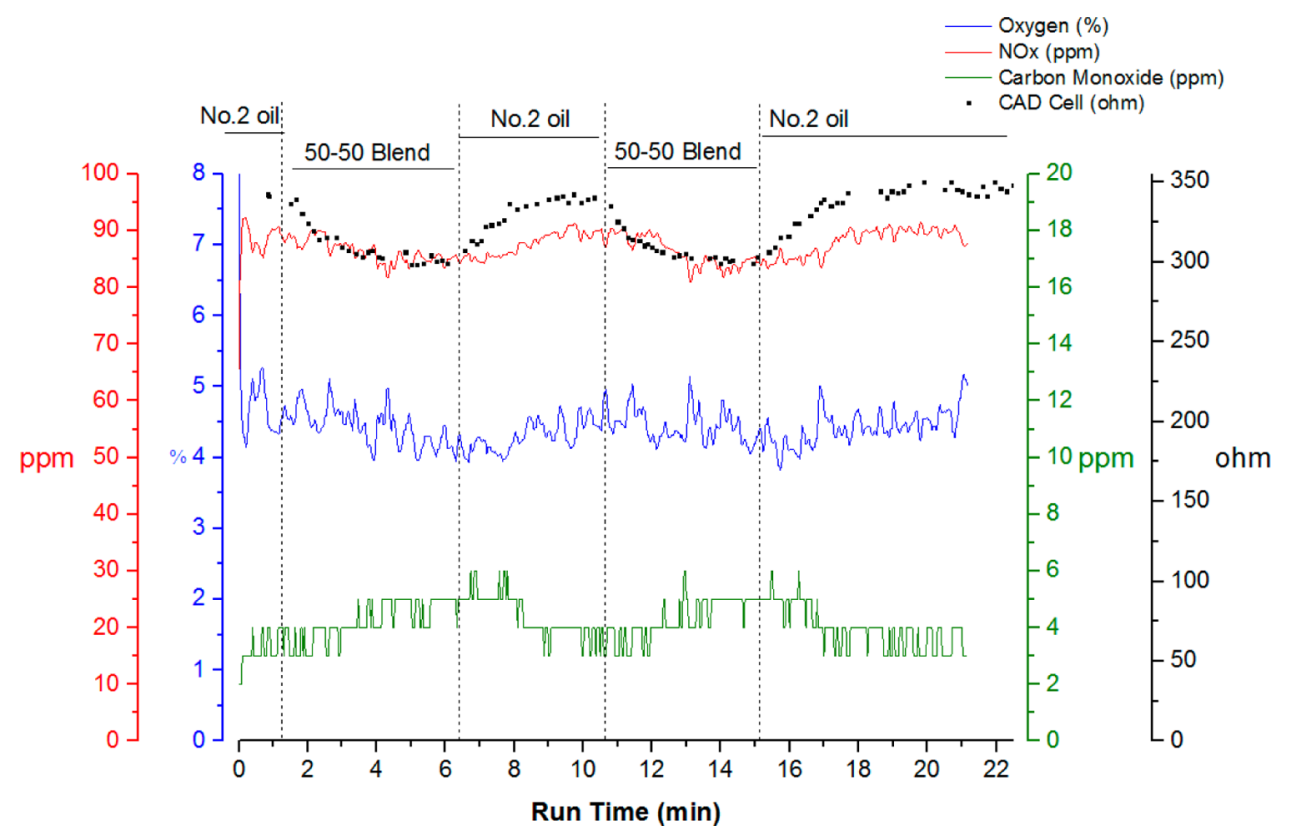

Figure 2. Effect of switching from ULSD to the $50 \% \mathrm{KiOR}$ distillate fuel blend on $\mathrm{NO}_{x}, \mathrm{O}_{2}, \mathrm{CO}$, and cad cell resistance.

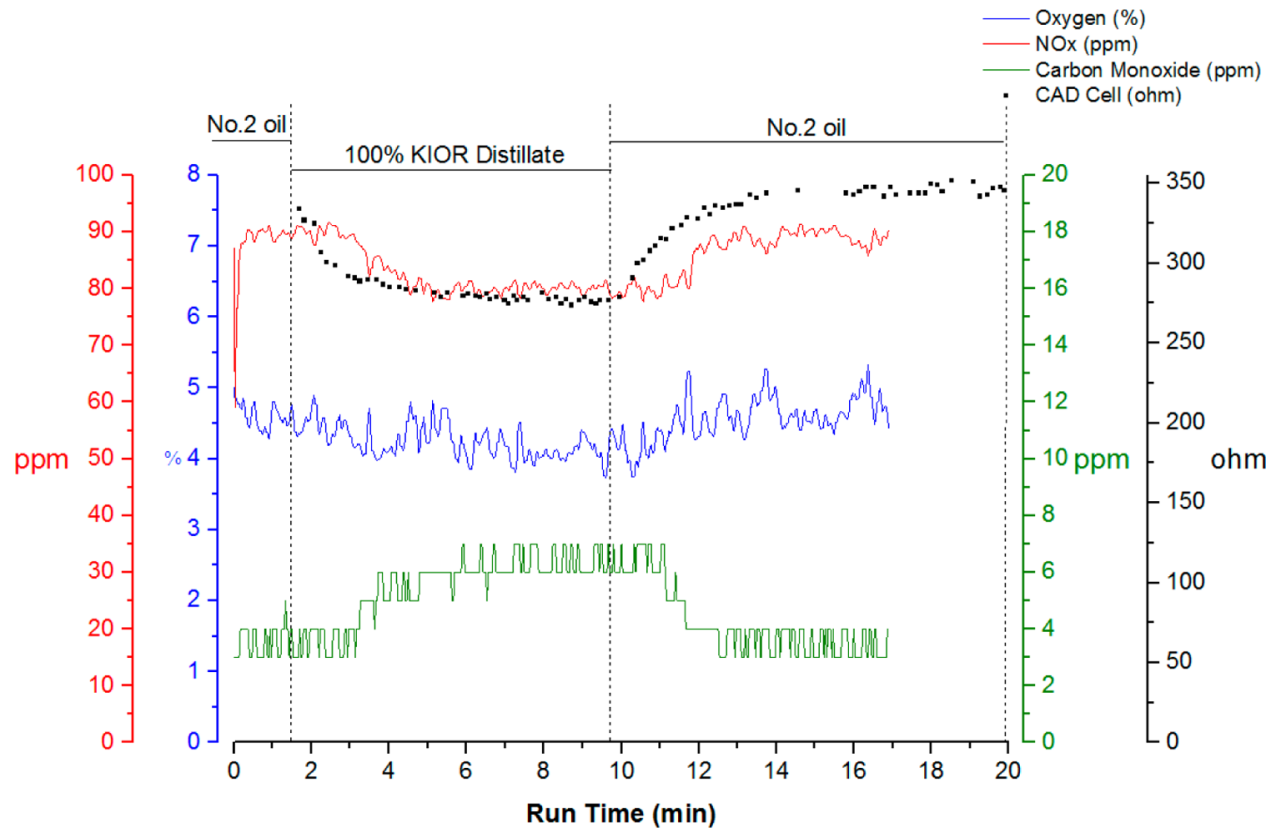

Figure 3. Effect of switching from ULSD to the $100 \% \mathrm{KiOR}$ distillate fuel blend on $\mathrm{NO}_{x}, \mathrm{O}_{2}, \mathrm{CO}$, and cad cell resistance.

no more than $15 \mathrm{ppm}$; thus, KiOR distillate fuel can be considered as ultra-low-sulfur heating oil. Furthermore, the cold flow property of KiOR distillate reduces the chances of having cold-weather-related issues, such as filter clogging, when used during cold winter seasons. Typically, outdoor standalone heating oil storage tanks are susceptible to cold winter temperatures, and as a consequence, the oil within the tank could form wax crystals, which can reduce the mobility of fuel, clog filters, and eventually prevent the fuel from reaching the furnace. With these issues in mind, the KiOR distillate fuel may be advantageous relative to other potential alternative fuels.

The KGO fuel on the other hand does not meet a number of the ASTM D396 ${ }^{8}$ specification requirements. The most obvious ones include viscosity and density. As shown in Table 1, the KGO had a density of $958 \mathrm{~kg} / \mathrm{m}^{3}$ and a viscosity of
$834 \mathrm{~mm}^{2} / \mathrm{s}$; both values are higher than the maximum allowed specification in ASTM D396. ${ }^{8}$ Also, it narrowly meets the pour point specification. The sulfur content (5.6 ppm) appears to be the main advantageous property of KGO that could enable it use as fuel oil in applications where No. 4, 5, and 6 grades are used. Practically, the KGO could be considered for industrial heating where residual fuel oil (fuel oil No. 6) is primarily used.

3.2. Combustion Test in a Transparent Quartz Chamber. The steady-state flame characteristic, specifically flame luminosity and shape, obtained from the combustion of the test fuel blends and the 100\% ULSD in the transparent quartz chamber are shown in Figure 1. As mentioned earlier, the combustion operating conditions were established with the pure ULSD and the same conditions were used for the three test fuels. Visually, it was found that the luminosity of the $50 \%$ 


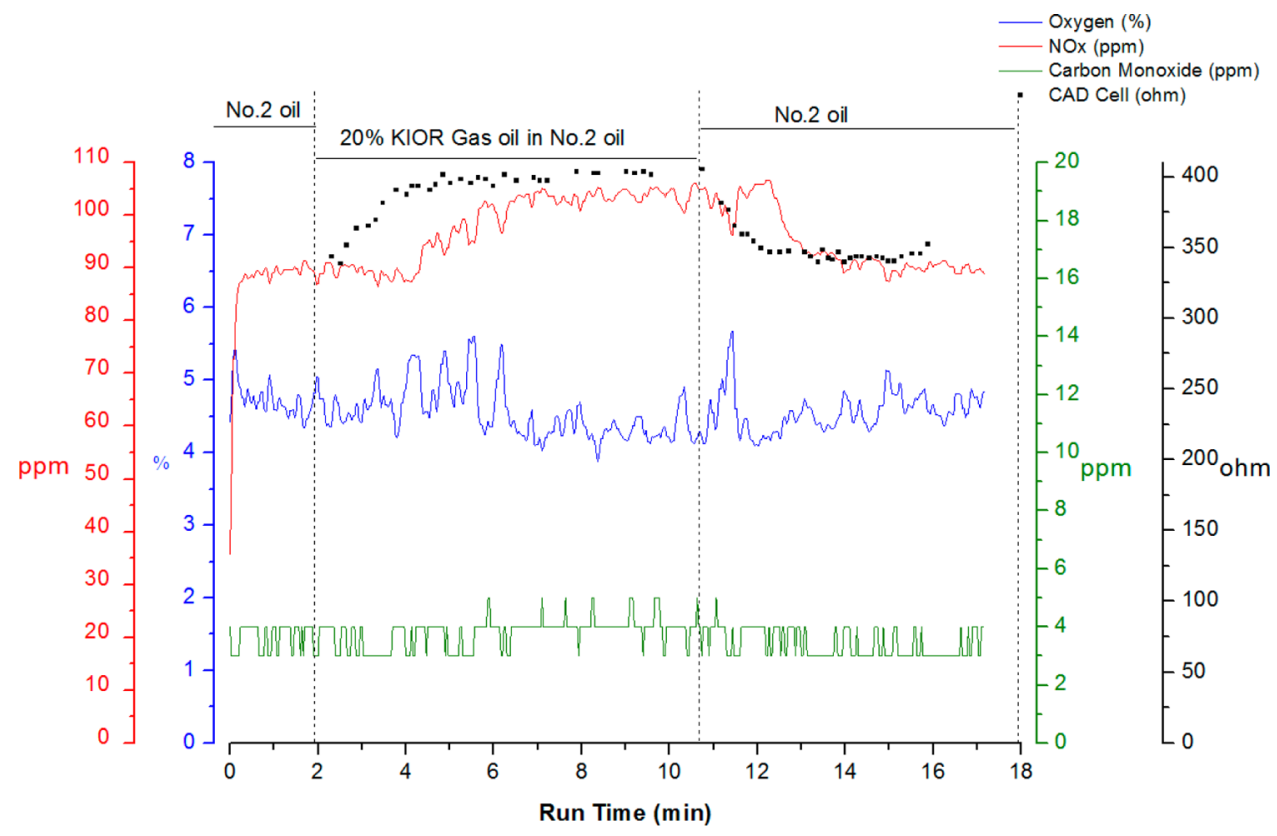

Figure 4. Effect of switching from ULSD to the $20 \% \mathrm{KGO}$ blend fuel on $\mathrm{NO}_{x}, \mathrm{O}_{2}$, $\mathrm{CO}$, and cad cell resistance.

KiOR distillate blend and the 100\% KiOR distillate fuels were both comparable to that of the pure ULSD fuel. In contrast, the flame luminosity for the $20 \%$ KGO blend fuel appeared different and made the quartz chamber slightly transparent. In general, all of the test fuel flames were stable with excellent retention to the burner head. It was difficult to identify differences in the shape/structure of the flames of the $50 \%$ KiOR distillate blend and the $100 \% \mathrm{KiOR}$ distillate with that of the pure ULSD. However, the $20 \%$ KGO flame appeared to be relatively thinner and longer than all of the test fuels. These changes could be caused by higher viscosity and higher aromatic content in this fuel blend. In summary, the results of the test in the quartz chamber indicated that both the $100 \%$ KiOR distillate and 50\% KiOR distillate blend fuels have similar combustion characteristics to the pure ULSD fuel.

3.3. Combustion Test in a Residential Boiler. The combustion of the fuel blends were successfully completed in the Dunkirk 3EW residential boiler. Overall, the results indicated that the test fuels performed satisfactorily. Figures 2-4 show the trends for the cad cell resistance and the concentrations of $\mathrm{NO}_{x}, \mathrm{CO}$, and $\mathrm{O}_{2}$ in the flue gas for each fuel blend. From Figure 2, it can be seen that switching from ULSD to the $50 \%$ KiOR distillate fuel blend resulted in a gradual decrease in $\mathrm{NO}_{x}, \mathrm{O}_{2}$, and the cad cell resistance with an increase in the concentration of $\mathrm{CO}$ emission. Likewise, the transition from ULSD fuel to $100 \%$ KiOR distillate as shown in Figure 3 indicated a higher increase in $\mathrm{CO}$ emission and a decrease in both $\mathrm{NO}_{x}$ and cad cell resistance. On the other hand, the change from ULSD to the $20 \% \mathrm{KGO}$ fuel blend caused an increase in $\mathrm{NO}_{x}$ emission and cad cell resistance without an obvious effect on $\mathrm{CO}$ emission (Figure 4). On CO, it should be noted that all of the $\mathrm{CO}$ levels measured are extremely low and can be considered near-negligible, with any differences within the accuracy of the instrument. For residential home oil burners, a $\mathrm{CO}$ level under $25 \mathrm{ppm}$ is considered clearly acceptable.

The steady-state emission values and the cad cell resistance are shown in Table 2. The emission levels are comparable to previous studies on oil-fired boilers. ${ }^{3}$ For ULSD, the average
Table 2. Steady-State Emission Concentrations and Cad Cell Resistance Values

\begin{tabular}{llccc} 
& \multicolumn{4}{c}{ summary of combustion results } \\
\cline { 2 - 5 } \multicolumn{1}{c}{ parameter } & ULSD & $\begin{array}{c}\text { 100\% KiOR } \\
\text { distillate }\end{array}$ & $\begin{array}{c}50 \% \text { KiOR } \\
\text { distillate }\end{array}$ & $\begin{array}{c}20 \% \text { KiOR } \\
\text { gas oil }\end{array}$ \\
oxygen $(\%)$ & 4.57 & 4.20 & 4.37 & 4.51 \\
$\mathrm{NO}_{x}(\mathrm{ppm})$ & 89.37 & 80.17 & 84.26 & 101.26 \\
CO $(\mathrm{ppm})$ & 3.59 & 6.09 & 4.77 & 3.91 \\
$\begin{array}{l}\text { smoke number } \\
\text { cad cell resistance } \\
(\Omega)\end{array}$ & 342 & 279 & 301 & 399 \\
\hline
\end{tabular}

$\mathrm{NO}_{x}$ and $\mathrm{CO}$ concentrations were 89.3 and $3.6 \mathrm{ppm}$, respectively. In the case of the $50 \% \mathrm{KiOR}$ distillate blend, the average $\mathrm{NO}_{x}$ was $84.3 \mathrm{ppm}$ and $\mathrm{CO}$ was $4.8 \mathrm{ppm}$. For the combustion of $100 \% \mathrm{KiOR}$ distillate fuel, the steady-state $\mathrm{NO}_{x}$ was $80.2 \mathrm{ppm}$ and $\mathrm{CO}$ was $6.1 \mathrm{ppm}$. The combustion of the $20 \%$ KGO produced $\mathrm{NO}_{x}$ of $101.3 \mathrm{ppm}$ and $\mathrm{CO}$ of $3.9 \mathrm{ppm}$. This means that the change from ULSD to the $50 \% \mathrm{KiOR}$ distillate resulted in a 5.7\% decrease in $\mathrm{NO}_{x}$ emission. Also, the pure KiOR distillate produced $11.4 \%$ less $\mathrm{NO}_{x}$ when compared to the ULSD. The lower amount of $\mathrm{NO}_{x}$ produced from the $\mathrm{KiOR}$ distillate fuel could be because it contained less amount of fuel-bound nitrogen. Likewise, the higher amount of $\mathrm{NO}_{x}$ formation from the combustion of $20 \%$ KGO may be attributed to a higher fuel-bound nitrogen content in KGO. Also, it should be pointed out that thermal $\mathrm{NO}_{x}$ from atmospheric nitrogen could play a role because it is influenced by the combustion temperature. ${ }^{35}$ Thus, fuels that lead to higher temperatures in the burner area could promote $\mathrm{NO}_{x}$ formation via a thermal mechanism. In general, $\mathrm{NO}_{x}$ emission is an issue of concern in the combustion of fuels, but it is not currently regulated for small residential burners in states where heating oil is used. ${ }^{36}$ Studies suggest that techniques such as exhaust gas recirculation and retarded injection timing could be used to achieve lower $\mathrm{NO}_{x}$ emissions if needed. ${ }^{35,36}$

The result from the combustion studies of the pure KiOR distillate under cyclic conditions at a slow rate of $2 \mathrm{~h}$ per cycle 


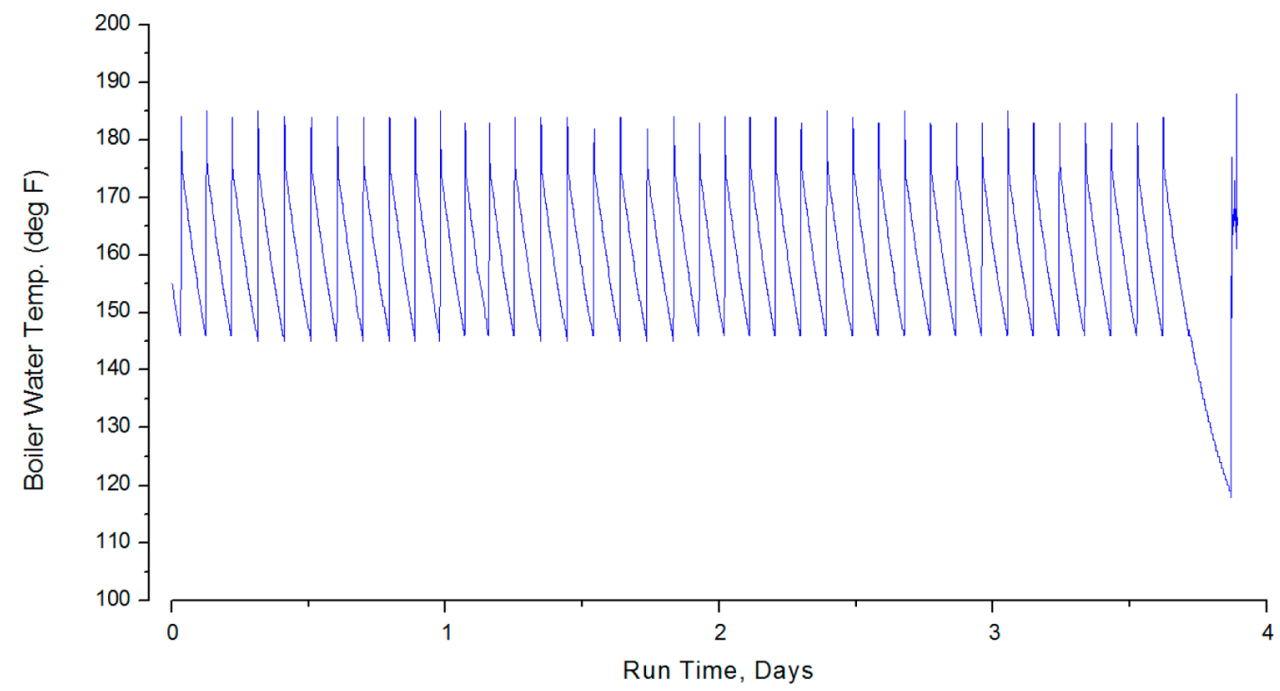

Figure 5. Boiler water temperatures showing the cyclic operation with the KiOR distillate for approximately 4 days.

over a period of 4 days is provided in Figure 5. The graph shows the boiler water temperature over the period of cyclic testing. The test was conducted to simulate actual operation of home-heating boilers where heat is demanded intermittently. The result clearly shows that the burner was able to operate in an on-and-off mode continuously on the pure KiOR distillate for the entire cyclic operation without any failure. Overall, the results from all of the combustion results are very positive and indicate that basic combustion performance is not likely to be a concern with these test fuel blends. However, higher blends of $\mathrm{KGO}$ could result in higher $\mathrm{NO}_{x}$ emissions.

3.3. Elastomer Compatibility and Stability Tests. Figure 6 shows the results from the elastomer compatibility

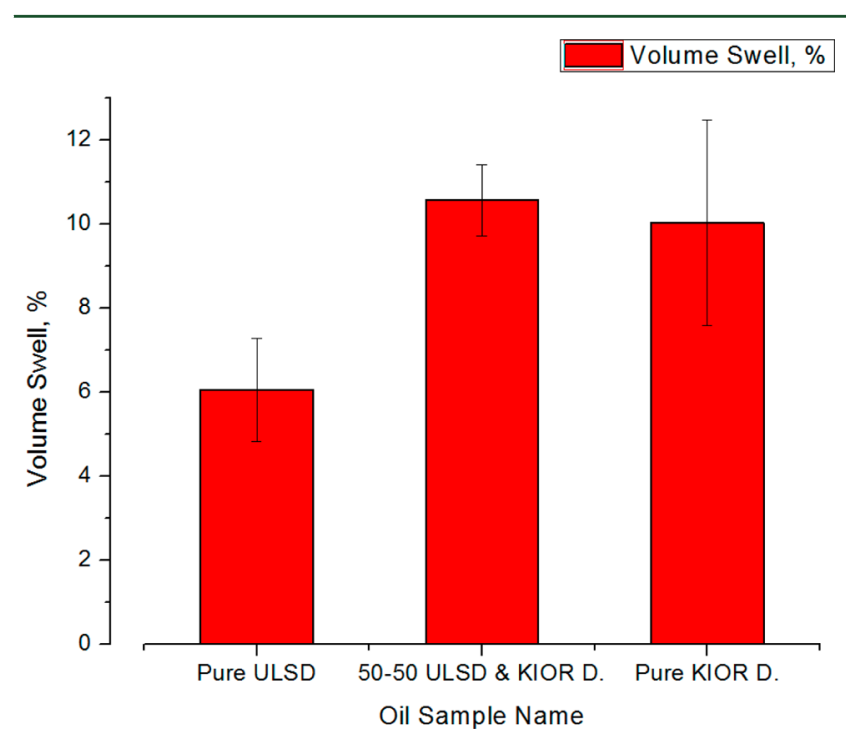

Figure 6. Fuel blend effect on the volume swell of nitrile slabs.

test based on the change in volume of the rectangular specimens after immersion in the fuels for 1 month at $43{ }^{\circ} \mathrm{C}$. The volume swells of the nitrile slabs determined by the dimensional change method were $6.05,10.56$, and $10.03 \%$ for ULSD, $50 \%$ KiOR distillate, and pure KiOR distillate, respectively. The $20 \% \mathrm{KGO}$ blend was not included in this study. The results showed that both the KiOR distillate and its blend caused the nitrile material to swell about $4.0 \%$ more than the ULSD. According to UL $179,{ }^{33}$ the criterion for acceptance is a volume swell less than $25 \%$ in a $72 \mathrm{~h}$ exposure. Therefore, the pump seal nitrile material could be considered compatible with the KiOR distillate and its fuel blends based on the fact that the testing condition used in this study was more aggressive (for 1 month).

Fuel stability is another important property to evaluate when considering the use of new fuels for heating applications. Technically, the fuel could change during handling, storage, and usage. $^{37}$ Studies have shown that diesel fuels and other alternative fuels, such as biodiesel, could undergo degradation reactions (e.g., oxidation, acid-base, condensation, and polymerization) when stored over an extended period of time. ${ }^{37}$ For heating applications, the degradation byproducts in a form of filterable insolubles could cause operability problems in storage tanks and burner fuel delivery systems.

Figure 7 shows the results from the stability test at $80^{\circ} \mathrm{C}$ for 1 week. In this study, the formation of filterable insolubles in

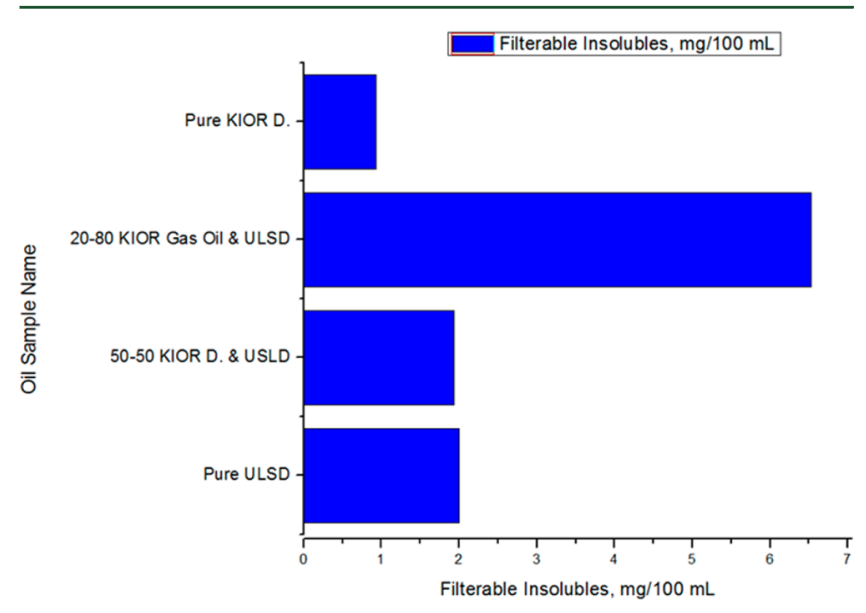

Figure 7. Fuel stability of the various fuel blends tested.

milligrams per $100 \mathrm{~mL}$ was used as a metric in evaluating the stability of the test fuels. Also, it is worthwhile to point out that the accelerated storage stability test at $80{ }^{\circ} \mathrm{C}$ for 1 week has been shown to have a good correlation with ASTM long-term test method D4625. ${ }^{34,39}$ The results showed that the amount of filterable insolubles formed in the pure HDCD, 50\% HDCD, 
$20 \% \mathrm{KGO}$, and ULSD were $0.93,1.93,6.53$, and $2.0 \mathrm{mg} / 100$ $\mathrm{mL}$, respectively.

According to ASTM D2274 $4^{38}$ and ASTM D5304 ${ }^{39}$ methods, the formation of filterable insoluble sediments up to $2.5 \mathrm{mg} /$ $100 \mathrm{~mL}$ in distillate fuels are considered as acceptable levels. ${ }^{37,40}$ This means that all of the test fuels were stable, with the exception of the $20 \%$ blend of $\mathrm{KGO}$, which formed a relatively high amount of insolubles. It is also worth pointing out that about $13.1 \mathrm{mg} / 100 \mathrm{~mL}$ of insolubles was filtered out of the $20 \% \mathrm{KGO}$ blend during the prefiltration step prior to the stability test. These results suggest that the $20 \% \mathrm{KGO}$ fuel blend may have stability issues. Excessive filterable insolubles carried by the fuel during oil burner operations could potentially cause blockage of the inlet filter, pump inlet strainer, nozzle body sintered metal, and eventually nozzle orifice. Hence, it is important that the fuels used in heating systems are stable.

\section{CONCLUSION}

The goal of this work was to evaluate biomass-derived "drop-in" fuels that have the potential to displace No. 2 fuel oil in homeheating systems. The study considered three test fuel blends: (1) $50 \%$ blend of the KiOR distillate in ULSD, (2) $100 \% \mathrm{KiOR}$ distillate, and (3) $20 \%$ blend of the KiOR gas oil in ULSD. The test fuels were successfully combusted, and their emission values were comparable to some extent with the ULSD base fuel. The findings indicate that the basic combustion performance is not likely to be a concern with these test fuel blends. Visual analysis of the flames in the quartz chamber clearly showed that the combustion of the pure KiOR distillate fuel and its blend is comparable to that of the ULSD fuel. The $20 \%$ blend of gas oil on the other hand was found to produce a slightly different flame characteristic; it was longer and of lower luminosity. The emission analysis revealed that the distillate fuels form less $\mathrm{NO}_{x}$ but the $20 \%$ gas oil blend produces more $\mathrm{NO}_{x}$ than the ULSD. Also, the distillate fuels in particular were found to have good elastomer compatibity and stability. On the basis of the results, it can be concluded that the KiOR distillates can be used as renewable HHO. With respect to the gas oil, higher blends could result in stability and elastomer compatibity issues, higher $\mathrm{NO}_{x}$ emissions, and cad cell resistance, which of course are all not desirable in burner operations. However, the gas oil could be considered for industrial heating where residual fuel oil (fuel oil No. 6) is primarily used.

\section{AUTHOR INFORMATION}

\section{Corresponding Author}

*Telephone: 631-344-7916. E-mail: butcher@bnl.gov.

\section{Notes}

The authors declare no competing financial interest.

\section{ACKNOWLEDGMENTS}

This work was performed with funding from BETO, DOE. The authors acknowledge the support, guidance, and encouragement from Elliott Levine, DOE.

\section{REFERENCES}

(1) U.S. Energy Information Administration (EIA). Heating Oil Explained; EIA: Washington, D.C., 2015; http://www.eia.gov/ energyexplained/print.cfm?page=heating_oil_use (accessed July 20, 2015).
(2) Bioenergy Technologies Office (BETO), U.S. Department of Energy (DOE)/Office of Energy Efficiency and Renewable Energy (EERE). Technical Information Exchange on Pyrolysis Oil: Potential for a Renewable Heating Oil Substitution Fuel in New England; Manchester, NH, May 9-10, 2012; pp 1-59.

(3) Corma, A.; Huber, G. W.; Sauvanaud, L.; O'Connor, P. Processing biomass-derived oxygenates in the oil refinery: Catalytic cracking (FCC) reaction pathways and role of catalyst. J. Catal. 2007, 247 (2), 307-327.

(4) Saidur, R.; Abdelaziz, E. A.; Demirbas, A.; Hossain, M. S.; Mekhilef, S. A review on biomass as a fuel for boilers. Renewable Sustainable Energy Rev. 2011, 15 (5), 2262-2289.

(5) Zhang, Q.; Chang, J.; Wang, T.; Xu, Y. Review of biomass pyrolysis oil properties and upgrading research. Energy Convers. Manage. 2007, 48 (1), 87-92.

(6) Batey, J. E. Combustion Testing of a Bio-diesel Fuel Oil Blend in Residential Oil Burning Equipment; Massachusetts Oilheat Council and National Oilheat Research Alliance: Burlington, MA, 2003.

(7) McDonald, R. Evaluation of Gas, Oil and Wood Pellet Fueled Residential Heating System Emissions Characteristics; Energy Sciences and Technology Department, Brookhaven National Laboratory: Upton, NY, 2009.

(8) ASTM International. ASTM Standard D396-15b, Standard Specification for Fuel Oils; ASTM International: West Conshohocken, PA, 2015; www.astm.org.

(9) ASTM International. ASTM Standard D6751-15a, Standard Specification for Biodiesel Fuel Blend Stock (B100) for Middle Distillate Fuels; ASTM International: West Conshohocken, PA, 2015; www. astm.org.

(10) Czernik, S.; Bridgwater, A. V. Overview of Applications of Biomass Fast Pyrolysis Oil. Energy Fuels 2004, 18 (2), 590-598.

(11) Oasmaa, A.; Czernik, S. Fuel Oil Quality of Biomass Pyrolysis OilsState of the Art for the End Users. Energy Fuels 1999, 13 (4), 914921.

(12) Lehto, J.; Oasmaa, A.; Solantausta, Y.; Kytö, M.; Chiaramonti, D. Review of fuel oil quality and combustion of fast pyrolysis bio-oils from lignocellulosic biomass. Appl. Energy 2014, 116 (0), 178-190.

(13) Chiaramonti, D.; Oasmaa, A.; Solantausta, Y. Power generation using fast pyrolysis liquids from biomass. Renewable Sustainable Energy Rev. 2007, 11 (6), 1056-1086.

(14) Martin, J. A.; Boateng, A. A. Combustion performance of pyrolysis oil/ethanol blends in a residential-scale oil-fired boiler. Fuel 2014, 133 (0), 34-44.

(15) Farag, I. H.; LaClair, C. E.; Barrett, C. J. Technical, Environmental and Economic Feasibility of Bio-Oil in New Hampshire's North Country; Chemical Engineering Department, University of New Hampshire: Durham, NH, 2002.

(16) Bridgwater, A. V. Review of fast pyrolysis of biomass and product upgrading. Biomass Bioenergy 2012, 38, 68-94.

(17) Park, H.; Jeon, J.-K.; Suh, D.; Suh, Y.-W.; Heo, H.; Park, Y.-K. Catalytic Vapor Cracking for Improvement of Bio-Oil Quality. Catal. Surv. Asia 2011, 15, 161-180.

(18) Huber, G. W.; Corma, A. Synergies between Bio- and Oil Refineries for the Production of Fuels from Biomass. Angew. Chem., Int. Ed. 2007, 46 (38), 7184-7201.

(19) Taarning, E.; Osmundsen, C. M.; Yang, X.; Voss, B.; Andersen, S. I.; Christensen, C. H. Zeolite-catalyzed biomass conversion to fuels and chemicals. Energy Environ. Sci. 2011, 4 (3), 793-804.

(20) Elliott, D. C. Historical Developments in Hydroprocessing Biooils. Energy Fuels 2007, 21 (3), 1792-1815.

(21) Elliott, D. C.; Hart, T. R.; Neuenschwander, G. G.; Rotness, L. J.; Zacher, A. H. Catalytic hydroprocessing of biomass fast pyrolysis bio-oil to produce hydrocarbon products. Environ. Prog. Sustainable Energy 2009, 28 (3), 441-449.

(22) Zacher, A. H.; Olarte, M. V.; Santosa, D. M.; Elliott, D. C.; Jones, S. B. A review and perspective of recent bio-oil hydrotreating research. Green Chem. 2014, 16, 491-515. 
(23) French, R. J.; Hrdlicka, J.; Baldwin, R. Mild hydrotreating of biomass pyrolysis oils to produce a suitable refinery feedstock. Environ. Prog. Sustainable Energy 2010, 29 (2), 142-150.

(24) Lane, J. \$75M Secured for KiOR; Is Mississippi the New Leader in State-Level Biofuels Development?; http://www.biofuelsdigest.com/ bdigest $/ 2010 / 08 / 30 / 75 \mathrm{~m}$-secured-for-kior-is-mississippi-the-newleader-in-state-level-biofuels-development/ (accessed July 20, 2015).

(25) Lane, J. Biofuels Digest's 2012 Best Technology Extension Award: Envergent-Kapolei, HI; http://www.biofuelsdigest.com/bdigest/tag/ envergent/ (accessed July 20, 2015).

(26) Lane, J. New Breakthrough in Pyrolysis Sector Promises To Speed Commercialization; http://www.biofuelsdigest.com/bdigest/2010/11/ $26 /$ new-breakthrough-in-pyrolysis-sector-promises-to-speedcommercialization/ (accessed July 20, 2015).

(27) Dayton, D. C.; Carpenter, J. R.; Kataria, A.; Peters, J. E.; Barbee, D.; Mante, O. D.; Gupta, R. Design and operation of a pilot-scale catalytic biomass pyrolysis unit. Green Chem. 2015, 17 (9), 46804689.

(28) Marker, T.; Felix, L.; Linck, M.; Roberts, M. Integrated hydropyrolysis and hydroconversion process (IH2) for production of gasoline and diesel fuel from wood, algae, cornstover, lemna, and bagasse feedstocks. Proceedings of the Spring Meeting and 7th Global Congress on Process Safety; Chicago, IL, March 13-17, 2011.

(29) Marker, T. L.; Felix, L. G.; Linck, M. B.; Roberts, M. J. Integrated hydropyrolysis and hydroconversion (IH2) for the direct production of gasoline and diesel fuels or blending components from biomass, part 1: Proof of principle testing. Environ. Prog. Sustainable Energy 2012, 31 (2), 191-199.

(30) Tan, E. C. D.; Marker, T. L.; Roberts, M. J. Direct production of gasoline and diesel fuels from biomass via integrated hydropyrolysis and hydroconversion process-A techno-economic analysis. Environ. Prog. Sustainable Energy 2014, 33 (2), 609-617.

(31) ASTM International. ASTM Standard D2156-09, Standard Test Method for Smoke Density in Flue Gases from Burning Distillate Fuels; ASTM International: West Conshohocken, PA, 2013; www.astm.org.

(32) ASTM International. ASTM Standard D471-12a, Standard Test Method for Rubber Property-Effect of Liquids; ASTM International: West Conshohocken, PA, 2012; www.astm.org.

(33) Underwriters Laboratories. UL Standard 157, UL Standard for Safety of Gaskets and Seals; Underwriters Laboratories: Northbrook, IL, 1996.

(34) ASTM International. ASTM Standard D4625-14, Standard Test Method for Middle Distillate Fuel Storage Stability at $43{ }^{\circ} \mathrm{C}\left(110{ }^{\circ} \mathrm{F}\right)$;

ASTM International: West Conshohocken, PA, 2014; www.astm.org.

(35) Palash, S. M.; Kalam, M. A.; Masjuki, H. H.; Masum, B. M.; Rizwanul Fattah, I. M.; Mofijur, M. Impacts of biodiesel combustion on NOx emissions and their reduction approaches. Renewable Sustainable Energy Rev. 2013, 23 (0), 473-490.

(36) Butcher, T.; Krishna, C. R.; Celebi, Y.; Wei, G. NO $\mathrm{N}_{x}$-How low is achievable with oilheating combustion systems? Proceedings of the 2003 National Oilheat Research Alliance Technology Symposium; Boston, MA, June 9-10, 2003; BNL-71337-2003.

(37) Batts, B. D.; Fathoni, A. Z. A literature review on fuel stability studies with particular emphasis on diesel oil. Energy Fuels 1991, 5 (1), $2-21$.

(38) ASTM International. ASTM Standard D2274-14, Standard Test Method for Oxidation Stability of Distillate Fuel Oil (Accelerated Method); ASTM International: West Conshohocken, PA, 2014; www.astm.org.

(39) ASTM International. ASTM Standard D5304-15, Standard Test Method for Assessing Middle Distillate Fuel Storage Stability by Oxygen Overpressure; ASTM International: West Conshohocken, PA, 2015; www.astm.org.

(40) Litzke, W.-L. A Guide to Fuel Performance; National Oilheat Research Alliance: Alexandria, VA, 2004. 